\title{
Türkiye'de Profesyonel Futbolcuların Sendikalaşma Algıları
}

\author{
Recep CENGIZ1 (iD , Utku IŞIK² (D) , Göksel YIKMIŞ3 \\ ${ }^{1}$ Manisa Celal Bayar Üniversitesi, Spor Bilimleri Fakültesi, MANiSA \\ ${ }^{2}$ Recep Tayyip Erdoğan Üniversitesi, Beden Eğtiimi ve Spor Yüksekokulu, RizE \\ 3 Bingöl Üniversitesi, Fen Edebiyat Fakültesi, Felsefe Bölümü, BiNGÖL
}

Araştırma Makalesi

DOI: $10.53434 / g b e s b d .908025$

Öz

$\mathrm{Bu}$ araștırmanın amacı profesyonel futbolcuların sendikalaşmaya ilişkin algılarını belirlemektir. Profesyonel futbolcularda sendika faaliyetlerine katılım ve sendika bilincinin oluşması, futbolcu-kulüp ihtilaflarının çözümünde sendikanın rolü bu çalışmanın teorik alt yapısını oluşturmaktadır. Araştırmada nitel araştırma yöntemlerinden görüşme tekniği uygulanmıştır. Maksimum çeşitlilik örnekleme yöntemine göre seçilen 44 profesyonel futbolcuyla yarı yapılandırılmış görüşme soruları hazırlanarak görüşme yapılmıştır. Profesyonel futbolcuların sendikaların işleyişine, faaliyetlerine ve sorunlarına yönelik görüşleri belirlenmeye çalışllmıştır. Türkiye liglerinde profesyonel futbolcuların, futbol sendikalarına yönelik düşüncelerini belirlemek için toplanan veriler Maxqda programı kullanılarak içerik açısından analiz edilmiștir. Bu süreçte kodlar, kategoriler ve temalar haline dönüştürülmüştür. Araştırmanın tema özetlerine göre; profesyonel futbolcuların sendika konusunda olumlu bir algıya sahip olmadıkları saptanmıştır. Bunun yanı sıra birçok futbolcunun etiketlenme korkusu nedeniyle sendikalara üye olmadığı, sendikaların düzenlemiş olduğu etkinliklere katılımın çok düşük olduğu, futbolcuların kulüpleriyle ihtilaflarının çözümde sendikanın sınırlı rol oynadığı, hak arama noktasında menajerlerin daha fazla yol gösterici olduğu anlaşılmaktadır. Araştırma sonuçlarına dayalı olarak sendikacılıkta sadece futbol çalışanlarını değil, diğer spor çalışanlarını da içine alacak şekilde ortak platformlar yaratılması önerilebilir.

Anahtar sözcükler: Futbol, Kulüpler, Profesyonel futbolcu, Sendika 


\title{
Unionization Perception of Professional Football Players in Turkey
}

\begin{abstract}
The aim of this study is to determine the perceptions of professional football players about unionization. Participation in trade union activities and the formation of union consciousness in professional football players, the role of the union in the solution of football-club disputes constitute the theoretical infrastructure of this study. Interview technique, one of the qualitative research methods was used in the research. Semi-structured interview questions were prepared and interviews were conducted with 44 professional football players selected according to the maximum diversity sampling method. The opinions of professional football players on the functioning, activities and problems of the trade unions were tried to be determined. Professional football league in Turkey, the main ideas collected to determine their thoughts for football unions, have been analyzed in terms of content using in Maxqda. According to the study summary of the research; it is determined that professional football players do not have a positive perception about trade union. In addition to this, it is understood that many football players are not members of the trade unions because of fear of being tagged, participation in the activities organized by trade unions is very low; Based on the results of the research, it may be suggested to create common platforms in trade unionism to include not only football staffs but also other sports employees.
\end{abstract}

Keywords: Football, Clubs, Professional football player, Trade union

\section{Giriş}

Her insan faaliyetinde olduğu gibi, futbol için de gereksinim olan sendikalaşma, futbol çalışanlarının kulüp ilişkilerinde ortaya çıkan ve tek başlarına çözemeyecekleri, hatta ifade bile edemeyecekleri ekonomik, sağlık ve güvenlik gibi istismar edici davranışlara karşı demokratik, ekonomik ve özlük haklarını korumak ve geliştirmek amacıyla ortaya çıkmış bir birleşme hareketidir (Kayıkçı, 2013; Şişman, 2004).

Kelime anlamı olarak sendika, Türk Dil Kurumu güncel Türkçe sözlüğünde "İşçilerin veya işverenlerin iş, kazanç, toplumsal ve kültürel konular bakımından çıkarlarını korumak ve daha da geliştirmek için aralarında kurdukları birlik" olarak belirtilmektedir. 2821 sayılı Sendikalar Kanunu madde 2'de ise, sendika "işçilerin veya işverenlerin çalışma ilişkilerinde, ortak ekonomik ve sosyal hak ve menfaatlerini korumak ve geliştirmek için meydana getirdikleri tüzel kişiliğe sahip kuruluşlar" şeklinde ifade edilmektedir (Sendikalar Kanunu, 1983).

Daud ve Tumin (2003) ise sendikayı; tazminat hakkı, iş güvenliği, haksız işten çıkarma gibi birçok konuda, çalışanların hakkını savunan, işveren ile çalışanların hakları konusunda toplu pazarlıklar yürüten bir organizasyon olarak tanımlamıştır. Bu tanımlara göre sendikalardan, sosyal taraflardan birisi olan ve federasyonu temsil eden kulüplerle sürekli temas halinde olması, üyelerinin menfaatlerini koruması, istihdam, transfer piyasası ve eğitim politikaları gibi alanlarda yeni ve yenilikçi politikalar üretmesi beklenmektedir (Tekeş, 2010). Bu misyonun gerçekleştirilmesi adına 1983'te Fulmer (aktaran Aksu, 1998) ise, sendika fonksiyonlarını; ücret arttırımı, çalışma koşullarının düzenlenmesi, çalışanlara ücret dışında fayda sağlanması, işgörenin korunması, politik güçlerin harekete geçirilmesi, iletişim ve işgörenlerin kişisel ve sosyal ihtiyaçlarının karşılanması olarak belirtmektedir (Akcan, Polat ve Ölçüm, 2017). 
Sendikalar demokrasi, insan hakları ve bu haklarla bir bütün olan sendikal hakların en geniş biçimde yaşam bulduğu toplumsal bir örgütlenmedir (Gül, 2007). Bu sendikaların içinde faaliyet gösteren ve yeni bir kurumsal süreç olan "spor sendikaları" da bulunmaktadır (Şaşmaz-Ataçocuğu ve Zelyurt, 2016). Türkiye'de sendikalılaşma süreci, kulüplerin ve bireysel olarak futbolcuların artan gelirleriyle birlikte önemli oranda artmış ve bu artış da çeşitli uyuşmazlıkları beraberinde getirmiştir. Bu bağlamda küresel ekonominin etkisiyle endüstriyel bir işkoluna dönüşen profesyonel futbolda; sözleşmelerden doğan hak ihlalleri, kısıtlama ve yasaklamalara karşı futbolcuların haklarını koruma, geliştirme ve müzakere etme ihtiyacı oluşmuştur. Bu amaçla 2 Aralık 1907 tarihinde İngiltere Profesyonel Futbolcular Sendikası olan adını daha sonra Profesyonel Futbolcular Birliği (PFA) olarak değiștiren ve dört binden fazla üyesi bulunan profesyonel futbolcu sendikası kurulmuştur (Uluyol, 2014). Bu oluşumun en bilinen ve güçlü örneğini de Uluslararası Profesyonel Futbolcu Sendikaları Federasyonu (FIFPro) oluşturmaktadır (Aydın, Yüce, Yalız ve Demirkaya, 2017). Kurulan sendikaların faaliyetlerine bakıldığında ise Fransa Ulusal Profesyonel Futbolcular Birliğinin (UNFP) sözleşmeleri bitmiş ve yeni bir takım bulamamış futbolcular için yaz aylarında antreman seansı düzenlediği, futbolcuların korunması ve gelişmesi ile ilgilendiği; İtalya Futbolcular Birliğinin (AIC) profesyonel ve amatör liglerinde oynayan futbolcuların özlük haklarına sahip çıktığı; İspanyol Futbolcular Derneğinin (AFE) futbolcuların, gerek sportif kariyerleri boyunca gerekse futbolu bıraktıktan sonraki haklarını koruma gayesi ile çalıștığı; Almanya Sözleşmeli Futbolcular Birliğinin (VDV) FIFpro'da üyesi bulunan VDV üyelerinin hak ve menfaatlerini korumak adına hukuki yardımda bulunmakla birlikte, emeklilik primlerinin geri ödenmesi, prim anlaşmalarının incelenmesi hususunda yardımda bulunmakta ve sözleşmesi biten futbolculara antrenman olanağı sunduğu görülmektedir (Aydın, Yüce, Yalız ve Demirkaya, 2017; Yensi-Güven, 2013).

Modern futbolun temel sorunları arasında futbolcuların ekonomik ve özlük hakları yer almaktadır. Profesyonel futbolcu ise ekonomik ve özlük haklarını korumak için transfer olduğu kulüpte futbol oynamak zorundadır. Futbolcu bu süreçte performansının karşılığını almak isteyecek ve kulüp yöneticilerinin ekonomik ve özlük haklarını ihlal etmesine olanak tanımayacaktır. Bu mücadele gücü örgütler aracılığı ile yani sendika ile sağlanabilir.

Sendikaların, ekonomik ve özlük hakları korumasına yönelik Avrupa'da yer alan futbolcu sendikalarına bakılacak olursa, bu sendikaların kurumsal bir yapı içerisinde yaygın ve etkin olarak faaliyet gösterdiği görülmektedir. Bu çalışma sisteminin, Arsenal FC'nin 1886 yılında Kraliyet Cephane fabrikası işçileri tarafından, Aston Villa'nın 1874 yılında Villa Cross Şapeli tarafından, Eveton FC'nin 1878 yılında St. Domingo kilisesi ve Manchester United Newton Heath'teki Demiryolu işçileri tarafindan kurulmasıyla, profesyonellik kadar işçi sınıfının mücadelesiyle geliştiği bu sürece organizasyon yeteneğinin de katkı sağladığı söylenebilir (Irak, 2013). İtalya'da ise artan ırkçılığa karşı tepki göstermek adına profesyonel futbolcu sendikası kararı doğrultusunda maçların 5 dakika geç başlatılması kararı alınmıştır. Şili Profesyonel Futbolcular Birliği (SíFUP) tarafından yapılan açıllamada ise, 2016-2017 sezonunda, futbol ligleri yönetmeliğinde küme düşme ve yükselme konusunda yapılan değişiklikler ile futbolcu maaşlarının 
ödenmemesini protesto etmek amacıyla liglerin ertelenmesi için oy birliğiyle greve gitme kararının alınmıștır. İngiltere'deki duruma yönelik PFA'in faaliyetlerini özetlemek gerekirse; İngiltere'deki profesyonel futbolcuların yılda 4 hafta ücretli izin hakkına sahip olması, futbolcuların kulüp izni olmaksızın medyada özgürce açıklama yapma hakkını elde etmesi, sakatlanan futbolcuya sakatlık döneminde de ücret ödenmesi, hayatını kaybeden futbolcunun ailesine maddi yardım (40.000 pound) sağlanması, futbol liginin sağladığı özel sağlık sigortası ile sakatlanan futbolculara ekonomik yük olmaksızın tedavilerinin sağlanması, iş piyasasındaki işveren (kulüp) ve federasyonun (FA ve FL) tek yönlü uygulamalarının kaldırılması, sporcu ortalama ücretlerinin artırılması, transfer sisteminde futbolcuların aleyhine olan ve özellikle transfer ücreti ile futbolcuya ödenen ücretin sınırlandırılmasına yol açan "tavan ücret" uygulamasının kaldırılması gibi diğer kazanımların sendika aracılığı ile elde edildiği görülmektedir (Aydın, 2009).

Türkiye'de spor alanındaki sendikalaşma sürecine bakıldığında, 31 Mayıs 1965 tarihinde, İstanbul Genel İşler İşkolunda, Türkiye Profesyonel Futbolcular Sendikası adıyla ilk sendika kurulmuştur. 1969 yılındaki Genel Kurulda ise tüzük değișikliği ile sendikanın adı "Türkiye Profesyonel Futbolcular, Antrenörler, Menajerler ve Monitörler Sendikası" olarak değiştirilmiş, 1975 yılındaki Genel Kurulda ise "Futbol-İş (Türkiye Futbolcular, Antrenörler, Masörler Sendikası)" olarak tekrar değiştirilmiş ve Türk-İş Konfederasyonu'na üye olma kararı alınmıştır. Amatör sporcular açısından da 70'li yıllarda Amatör Sporcular Derneği çatısı altında örgütlenme faaliyetleri yürütülmüş ve dernek bünyesinde yaklaşık 70 bin sporcu yer almıştır. Dernek sendikalaşma çabası içindeyken 12 Eylül ile birlikte tüm faaliyetler son bulmuştur (Alay, 2007). 12 Eylül 1980 darbesi sonrası kapatılan AFD ile tıkanan örgütlenme süreci, Spor Sen (2009) ve Spor Emek-Sen (2010) ile yeniden başlamıştır. Bu sendikalardan günümüzde aktif olan tek sendika ise, 2012 yılında resmi olarak kurulan ve 2013 yılında HAK-İ̧ Sendikasına katılma kararı alan Futbol Çalışanları Sendikası'dır. Bu sendika yeni bir oluşum olup yeterince üye sayısına ulaşamadığı için henüz bir gücü ve etkinliği söz konusu değildir. Bu nedenle, profesyonel futbolcuların sendikal örgütlenme süreç ve doğasını incelemenin ihtiyaç olduğu düşünülmektedir (Furtun, 2013).

İlgili literatür incelendiğinde; sorunların tek bir elden çözülmesi, çalışma ve sözleşme koşullarındaki olumsuzlukların ortadan kaldırılması, üyelerin menfaatlerinin korunması, çalışma şartları ve antrenman koşullarının iyileștirilmesi, kamp sıklığı ve sürelerinin düzenlenmesi, transfer, maaş ve primlerin zamanında ve tam ödenmesi, sakatlıklarda oluşacak ekonomik kayıpların karşılanması, sahip olunan haklar konusunda bireylerin bilinçlendirilmesi ve onların sosyal ve kültürel anlamda desteklenmesi, iş ve sosyal güvence gibi yaşanan pek çok karmaşık sorunun ve çarpıklı̆̆ın ortadan kaldırılması için sporcuların sendikalaşmasını işaret ettiği görülmektedir (Alay, 2007; Atalay, 2012; Aydın, Yüce, Yalız ve Demirkaya, 2017; Balcı, 2013; Bostancı, 2013; Nasöz ve Demirkol, 2014; Yensi-Güven, 2013; Zelyurt ve Şaşmaz Ataçocuğu, 2014). Gerçekleştirilen çalışmalar doğrultusunda, bu araştırmanın, profesyonel futbolcuların sendikaya yönelik algı düzeylerini tespit ederek, literatüre katkı sağlayacağı düşünülmektedir. 
Söylemlerde tespit edilen meşrulaştırma biçimlerinin ve çeşitli anlamlandırma çabalarının, var olan durumun değişmeden sürmesine neden olan ve ortak çözüm çabalarını engelleyen bir işlevi olduğunun saptanması, profesyonel futbolcuların yaşananları nasıl ele aldığının, anlattığının, ne tür meşrulaştırma süreçleri içerisinde olduğunun gösterilmesi açısından, bu betimsel araştırmanın oldukça önemli olduğu düşünülmektedir.

Bu çalışmada küresel ekonominin etkisiyle endüstriyel bir işkoluna dönüşen futbolda, profesyonel çalışanların sendikaya üye olup olmadıklarının tespiti öncelikli olmayıp, çalışma koşullarının insani ve sportif gereksinimlere uygun olup olmadığı, sendikanın bu gereksinimine yanıt verip vermediği; sendikalı olma amacı ve elde edilen sonuçlarının neler olduğu, sendikal kazanımların öngörüsüne sahip olup olmadıklarının belirlenmesi amaçlanmaktadır. Dolayısıyla bu araştırmada, futbol sendikalarının işleyişi ve faaliyetlerinin sendikaya üye olan ve olmayan profesyonel futbolcuların algısı ile tespit edilmesi hedeflenmekte, sendikaların işleyişine yönelik sorunların bilimsel bir çalışma ile ortaya konulmasının, Türkiye'de spor alanında sendikacılığın gelişimine katkı sağlayacağı düşünülmektedir.

Bu bağlamda bu araştırmanın amacı, Türkiye'deki profesyonel futbolcuların çalışma koşulları ve sendikalaşma konusundaki düşünce ve görüşlerinin belirlenmesidir. Bu amaca yönelik olarak aşağıda yer alan araştırma sorularına cevap aranmıştır:

1. Futbolcuların kulüp ortamında yaşadıkları sorunlar nelerdir?

2. Futbolcuların sendikal örgütlenmeye yönelik görüşleri nelerdir?

\section{Yöntem}

Türkiye'deki profesyonel futbolcuların çalışma koşulları ve sendikalaşma konusundaki düşünce ve görüşlerinin belirlenmesinin amaçlandığı bu çalışmada nitel araştırma yöntemi kullanılmıștır. Nitel araştırmalar, gözlem, görüşme, doküman analizi gibi veri toplama yöntemleri kullanılarak araştırılan durumun, doğal ortamında gerçekçi bir şekilde ortaya konulmasının amaçlandığı, diğer bir deyişle durum belirlemeye yönelik bir araştırma yöntemidir (Yıldırım ve Şimşek, 2013).

Profesyonel futbolcuların görüşlerinin ve önerilerinin betimlenmesinin katılımcıların bakış açısını görmeye imkan tanıyan, derinlemesine veri toplamayı amaçlayan araştırma yöntemi olan nitel araștırma yaklaşımıyla mümkün olduğu düşünülmüştür (Creswell, 2005).

Betimleyici ve var olan durumun belirlenmesine izin veren bir araştırma yöntemi olan nitel araştırma yöntemi, bir konuya ilişkin katılımcıların görüş, ilgi, beceri, yetenek, tutum vb. özelliklerinin belirlenmesinde kullanılması uygun olan bir araștırma yöntemidir. Nesnelerin, toplumların, kurumların, olayların doğasını ve özelliklerini tanımlamak ayrıca bu yöntemin amaçları arasında yer almaktadır.

Nitel veri toplama yöntemlerinden en sık kullanılanı görüşmedir ve bireylerin bakış açılarını, deneyimlerini, değer, duygu ve algılarını ortaya koyma özelliği göstermektedir 
(King ve Horrocks, 2010). Görüşmenin amacl, bireylerin araștırma konusuna ilişkin sahip olduğu kültürel kategorileri derinlemesine incelemektir (Rummel, 1968). Araştırma için yapılan görüșmelerin türünün belirlenmesinde sistematik bilgi toplamaya hizmet edecek ve araştırmacıya esneklik sağlaması nedeniyle yarı yapılandırılmış görüşme formundan yararlanılmaya karar verilmiștir.

Çalışma koşulları ve örgütlenme konusundaki düşüncelerin belirlenmesine ilişkin olarak profesyonel futbolcuların görüşleri, kendi koşulları içerisinde ve var olduğu şekliyle betimlenmeye çalışılmıştır. Yapılan çalışmada veriler derinlemesine incelenmiş ve veriler arasındaki ilişkiler ortaya konulmaya çalışılmıştır.

\section{Katılımcilar}

Araştırmanın nitel çalıșma grubunu 2015-2017 futbol sezonunda, Türkiye Futbol Federasyonu'na bağlı Spor Toto Süper Lig, PTT 1. Lig, Spor Toto 2. Lig ve Spor Toto 3. Liglerinde mücadele eden kulüpler ile sözleșme yapan 44 profesyonel futbolcu oluşturmaktadır. Bu çalışmada verilerinin toplanma güçlüğü nedeniyle örneklem alma yoluna gidilmiş ve katılımcıların belirlenmesinde maksimum çeşitlilik örnekleme yöntemi kullanılmıştır. Çalışma grubunu oluşturan profesyonel futbolcuların demografik özelliklerine yönelik bilgiler de Tablo 1'de ifade edilmiştir.

Araştırmanın ikinci boyutunda çalışmaya gönüllü olarak katılan 44 profesyonel futbolcunun görüşleri görüşme yöntemi kullanılarak yürütülmüştür. Çalışmanın bulgular kısmında verilen görüşme metinleri, her bir görüşülen kişi (GK) için GK 1, GK 2,... GK44 şeklinde numaralandırılmıştır. Deneklerin isimleri etik nedenlerle gizli tutulmuştur.

Tablo 1. Katılımcıların demografik özellikleri (n:44)

\begin{tabular}{lccc}
\hline Özellikler & Grup & $\mathbf{n}$ & $\mathbf{\%}$ \\
\hline \multirow{3}{*}{ Yaş } & $16-20$ & 6 & 13,6 \\
& $21-25$ & 13 & 29,5 \\
& $26-30$ & 23 & 52,2 \\
& $31+$ & 2 & 4,5 \\
\hline \multirow{3}{*}{ Lig Düzeyleri } & Süper Lig & 11 & 25,0 \\
& 1. Lig & 11 & 25,0 \\
& 2. Lig & 11 & 25,0 \\
& 3.Lig & 11 & 25,0 \\
Eğitim Düzeyi & Lise & 24 & 55,4 \\
& Lisans & 15 & 34,0 \\
\hline \multirow{3}{*}{ Gelir Düzeyi } & Lisansüstü & 6 & 13,6 \\
\hline Sendikaya & Düşük & 8 & 18,1 \\
Üyelik Durumları & Orta & 22 & 50,0 \\
\hline
\end{tabular}


Tablo 1'e bakıldığında katılımcıların 23'ünün (\%52.2) 26-30 yaş aralığında, 11'inin (\%25.0) 3. lig futbolcusu, 24'ünün $(\% 55,4)$ lise mezunu olduğu, 22 'sinin $(\% 50,0)$ orta düzey gelir seviyesinde 37 'sinin $(\% 84,0)$ ise spor sendikasına üye olmadığı görülmektedir.

\section{Verilerin Toplanması}

Araştırmada gerekli olan verilerin toplanabilmesi için katılımcılara sorulmak üzere yarı yapılandırılmış 4 tane soru hazırlanmıştır. Soruların hazırlanması öncesinde konu analizi yapılmış olup sorular yapılan bu analize dayalı olarak hazırlanmıştır. Hazırlanan sorular görüş alınmak üzere biri ölçme değerlendirme alanında, diğeri de nitel araştırmalar alanında uzman olan 2 öğretim üyesine gönderilmiştir. Uzman görüşü sonunda bazı soruların içeriklerinde bazı soruların da anlatım özellikleri üzerinde düzeltmeler yapılmıştır. Yarı yapılandırılmış sorulara ilişkin örnekler aşağıda yer almaktadır.

Futbolculara, Türkiye liglerinde oynayan profesyonel futbolcu olarak ne tür ekonomik sorunlar yaşamaktasınız?" ve "Türkiye liglerinde oynayan profesyonel futbolcu olarak ne tür sosyal sorunlar yaşamaktasınız?" gibi yarı yapılandırılmış sorular sorulmuştur.

Görüşmeler, bazı yönetici, antrenör ve futbolcularla yapılan öngörüşme sonrasında 44 aktif profesyonel futbolcuyla "yüzyüze" ve "telefon görüşmesi aracılığı" ile yapılmıştır.

Görüşme esnasında ses kayıt cihazına izin verilmediğinden futbolcuların görüşleri, bir bilgisayar aracılığıyla word belgesine yazılı olarak aktarılmıştır. Word belgesine aktarılan görüşme metinleri içerik çözümlemesine tabi tutularak konuyla ilgili belirli sorunsalları yansıtan temalara ayrılmıștır. Sadeleştirilen ve araştırma konusunu ilgilendiren metinleri temsil eden temalar; sendikal örgütlenmeye bakış açısı, kulüp ortamında yaşanılan sorunların çözümünde sendikanın rolü, araştırma sorunsalı olarak 3 başlık altında kategorize edilmiştir.

Araştırmanın verileri araștırmaya katılan profesyonel futbolcuların görüşleri ve elde edilen bulgular veri toplama aracı ile sınırlıdır. Araştırmaya katılan profesyonel futbolcuların görüşlerinde samimi ve gerçek düşüncelerini ifade ettikleri varsayılmaktadır.

Araştırmanın veri toplama süreci 2018 yılı öncesinde gerçekleştiği için etik kurul raporu gerektirmemektedir.

\section{Verilerin Analizi}

Yapılan literatür araştırmalarına dayanarak sendika sorunları ile ilgili hazırlanan sorular sendikalı olma-olmama nedenleri ve beklentiler başlıkları altında toplanmıştır. Yapılan görüşmeler için yarı yapılandırılmış sorulardan yaralanılmıștır. Türkiye liglerinde profesyonel futbolcuların, futbol sendikalarına yönelik düşüncelerini belirlemek için toplanan ana fikirler, Maxqda programı kullanılarak içerik açısından analiz edilmiş; kodlar, kategoriler ve temalar haline dönüştürülmüştür. 


\section{Geçerlik ve Güvenirlik}

Nitel araştırmalarda geçerlik ve güvenirlik ölçütleri belirlenirken çalışmanın türü dikkate alınmalıdır. Nitel durum çalışmasının en temel özelliği bir ya da birkaç durumun derinliğine araştırılmasıdır (Yıldırım ve Şimşek, 2013). Araştırmanın geçerliği için diğer araştırmacıların çalışılan durumun kendi durumlarına ne kadar uyduğunu anlamalarını sağlayacak kadar yeterli bilgi verilmesi önemlidir. Bu çalışmada durum çok özel olmakla birlikte durumun özelliğini ortaya çıkaracak tüm bilgiler sunulmaya çalışılmıştır. Durum çalışmalarında çalışma sonucunun anlamlı ve anlaşılır olması için araştırmacı yeterli tanım yaptıkları ve tüm süreçleri ayrıntılı bir biçimde açıkladıkları konusunda ikna eder. $\mathrm{Bu}$ çalışmada tüm veri toplama ve analiz süreçleri yeterli bir biçimde açıklanmıştır. Veri analiz yönteminde görüşmeler yazılı metin haline dönüştürülmüş ve iki farklı araştırmacı tarafından analiz edilmiştir. Daha sonra karşılaştırılan sonuçlarda farklı kategorilerde kodlanan kısımlar birlikte tekrar gözden geçirilmiş ve yeniden kodlanmıştır.

\section{Bulgular}

Tablo 2. Futbolcuların kulüp ortamında yaşadıkları sorunlar

\begin{tabular}{|c|c|c|c|}
\hline Kategori & Alt kategori & Kodlar & Kodların tanımlanması \\
\hline \multirow{5}{*}{$\begin{array}{l}\text { Kulüp } \\
\text { ortamında } \\
\text { yaşanılan } \\
\text { sorunlar }\end{array}$} & \multirow{2}{*}{ Ekonomik } & Maaş & $\begin{array}{l}\text { Zamanında almama } \\
\text { Sözleşmeye uymama }\end{array}$ \\
\hline & & Ücret Adeletsizliği & $\begin{array}{l}\text { Yabancı futbolcunun kayırılması } \\
\text { Adamcilık }\end{array}$ \\
\hline & \multirow{2}{*}{ Sosyal } & Çevre & $\begin{array}{l}\text { Kıskançlık, Dedikodu } \\
\text { Kamp yoğunluğu } \\
\text { Çalışma şartları }\end{array}$ \\
\hline & & Aile/Arkadaş & $\begin{array}{l}\text { Aileye zaman ayırmama } \\
\text { Sosyal yaşantının olmaması } \\
\text { Arkadaşlarla vakit geçirememe }\end{array}$ \\
\hline & Özlük Hakları & Adeletsizlik/İlgisizlik & $\begin{array}{l}\text { Sakatlıklar } \\
\text { Tesisler } \\
\text { Beslenme }\end{array}$ \\
\hline
\end{tabular}

Yapılan görüşmeler sonunda futbolcuların yaşadığı sorunlar Tablo 2'de görüldüğü gibi 3 alt kategoride toplanmıştır. Bunlar sırasıyla ekonomik, sosyal ve özlük haklarıdır. Ekonomik sıkıntılar alt kategorisine yönelik futbolcular, maaşların geç yatması ve ücret adeletsizliğinden oldukça fazla behsetmektedirler. Örneğin; GK3; “Önceki senelerde alacaklarım için kulübü şikayet ettim, küme düşünce kulübün ismini değiştirdiler, param uçtu gitti" şeklinde görüş belirtirken, yine GK35; "Maaşlarımız çok geç yatıyor, adamını bulan transfer yapıyor, boşta kalmamak için mecbur parasız oynuyoruz" şeklinde demeçler vermiştir. Sosyal sorunlar alt kategorisi ile ilgili olarak ise GK27; "Hemen her yerde kıskançlık, çekememezlik, gruplaşma ve dedikodu var, yenildiğimiz maç sonrası çarşıya çıkamıyoruz, taraftar bunaltıyor" şeklinde yanıt verirken; GK41; "Kamp süreleri çok uzun, kamplardan çocuklarıma zaman ayıramıyorum, hayatımız kamplarda geçiyor, kamplar çok sıkıcı, bunaltıyor" șeklinde görüş belirtmiștir. Futbolcuların özlük hakları alt kategorisine 
yönelik olarak ise GK18; "Alt liglerde imkanlar çok yetersiz, 3. ligin amatör kümeden farkı yok, malzeme kalitesiz, saha yok, kaldığımız tesisler çok kötü” şeklinde görüş belirtmiştir.

Tablo 3. Katılımclların sendikal örgütlenmeye yönelik görüşleri

\begin{tabular}{|c|c|c|c|}
\hline Kategori & Alt kategori & Kodlar & Kodların tanımlanması \\
\hline \multirow{4}{*}{ Sendikal Faaliyet } & \multirow{2}{*}{$\begin{array}{l}\text { Örgütlenme } \\
\text { Gereksiz }\end{array}$} & İhtiyaç Yok & $\begin{array}{l}\text { Menajer hakkımı korur } \\
\text { İyi Futbolcuyum } \\
\text { Ne değișecek ki? }\end{array}$ \\
\hline & & Etkisiz/Yetersiz & $\begin{array}{l}\text { Başkan ne derse o olur } \\
\text { Mücadele Güçleri Zayıf } \\
\text { Güvenmiyorum }\end{array}$ \\
\hline & \multirow{2}{*}{$\begin{array}{l}\text { Örgütlenme } \\
\text { Gerekli }\end{array}$} & Güvence & $\begin{array}{l}\text { Haksızlığa Karşı } \\
\text { Adetsizliğe Karşı }\end{array}$ \\
\hline & & Örgütlenme & $\begin{array}{l}\text { Futbol iş kolu futbolcu işçi } \\
\text { Endüstri } \\
\text { Teşvik etmek }\end{array}$ \\
\hline
\end{tabular}

Tablo 3'te katılımcıların sendikalaşmaya yönelik görüşleri ortaya konulmuştur. Yapılan görüşmeler sonucunda futbolcuların sendikal örgütlenmeye yönelik görüşleri örgütlenme gerekli ve gereksiz olmak üzere 2 alt kategori altında toplanmıştır. Futbolcuların belirli bir kısmının ise sporda sendikalaşmaya yönelik bilgisi bulunmamaktadır. Örgütlenme gereksiz alt kategorisine yönelik futbolculardan GK10 bu durumu; "Hakkımı menajerim arıyor, neden sendikaya ihtiyaç duyayım?" şeklinde açıklarken; GK18; "Yine boş anlaşmalara imza atılacak, yine primler zamanında ödenmeyecek, ne değișecek?” şeklinde sendikaların anlamsızlığına değinmiștir. Örgütlenme gerekli alt kategorisine yönelik futbolculardan GK30; "Alt liglerde şartlar çok zor, teşvik etmek gerekiyor, haksızlık çok fazla oluyor, güvencemiz yok, sendika şart, birilerinin korkmadan mücadele etmesi lazım, diye üye oldum" diyerek görüş belirtmiştir. Sendikanın gerekliliğini savunan GK41; "Seneye futbolu bırakacağım, sigorta ve primlerimi hesaplattım, hep eksik yatmış, sendikalı olsaydım, olmazdı" diyerek yanıt vermiştir.

\section{Tartışma ve Sonuç}

Bu çalışmada Türkiye'deki profesyonel futbolcuların çalışma koşulları ve sendikalaşma konusundaki düşünce ve görüşleri tespit edilmeye çalışılmıştır. Araştırmanın ana amacı, katılımcıların sendikalı olması ya da sendikalı olmaması değişkeninden bağımsız olarak, futbolcuların sendikaya ve sendikalaşmaya bakış açısını ortaya koymaktır. Bu bağlamda sendikalara üye olan ve üye olmayan futbolcularla görüşmeler yapılmış ve futbolcuların sendikalara karşı olan algıları araştırılmaya çalışılmıştır.

Araștırmada futbolcuların yaşadıkları ekonomik sorunlar incelendiğinde, katılımcılardan sendikalı GK3; "Önceki senelerde alacaklarım için kulübü şikayet ettim, küme düşünce kulübün ismini değiştirdiler, param uçtu gitti” şeklinde görüş belirtmiş dolayısıyla futbolcuların üst liglere göre çok kötü şartlarda ve düşük ücretlerle çalıştıkları ve ödemeler konusunda ciddi sorunlar yaşadıkları saptanmıştır. Bir ücretlendirme sistemi 
olarak görülmemekle birlikte, futbol sektöründe genellikle motivasyon aracı ya da ödüllendirme olarak, değișen miktarlarda olmak üzere, galibiyet veya beraberliklerde verilen primlerin de zamanında ve tamamının ödenmediği anlaşılmaktadır. Şaşmaz Ataçocuğu ve Zelyurt (2016)'a göre ücretlerinin bir kısmı peşin, bir kısmı taksitlendirilen futbolcuların, ücretlerini zamanında ve tamamını alamama gibi durumlarla karşılaştıkları bilinmektedir. Aydın vd. (2016) tarafından yapılan bir çalışmada da profesyonel futbolcularla ilgili çalışmasında katılımcıların "Türk futbolunda ücretler zamanında ödenmiyor" sorusuna \%55,7 oranında katılıyorum yanıtı vermeleri araştırmadan elde edilen bulguları destekler niteliktedir.

Bu görüşlere karşın sendikasız GK11 (Süper Lig) "Bazılarına göre daha avantajlı hissediyorum. 2. ve 3. Ligde oynayan arkadaşlarımıza göre ekonomik açıdan daha avantajlıyız" demiştir. Bu söylem, katılımcının bazı dezavantajları kişisel telkinle telafi ettiği izlenimi uyandırmıştır. Nitekim başka bir katılımcı olan sendikalı GK3 (Süper Lig), "Takıma giremediği günlerde alacaklarının ödenmesi konusunda yöneticilerin sıkıntı çıkarmadığını" ifade etmiştir. Bu noktada katılımcılardan sendikalı GK3 ile sendikasız GK11'in ifadelerinin benzer olması dikkat çekmektedir. Elde edilen görüşlere göre futbolcuların daha kötü çalışma koşullarıyla karşılaştırma yaparak, yaşadıkları durumu normalleștirdikleri görülmüştür. Bunun yerine daha iyi seçeneklerle karşılaştırma yapıldığında olası sonuçların neler olacağı, bunun nasıl anlamlandırılacağı ve anlatılacağı ise bir başka araştırmanın konusudur. Şaşmaz Ataçocuğu ve Zelyurt (2016)'un profesyonel futbolda emek sermaye ilişkisini konu alan araștırma sonuçlarına göre 2. ve 3. ligde oynayan futbolcuların, üst liglere göre düşük ücret aldıkları, imzaladıkları sözleşmelerin, yöneticilerle anlaştıkları ücretlerle örtüşmediği bulguları araştırma bulguları ile paralelik göstermektedir. Karaman (2018) tarafından yapılan bir araştırmanın Süper Lig'de futbol oynayanların ekonomik durumu üç büyük kulüp oyuncuları kadar olmasa da günümüz koşullarında iyi sayılır. Asıl sıkıntıyı, TFF 1. Lig'deki bazı takımlar ile ikinci ve üçüncü ligde ter akıtan oyuncular yaşıyor. Kulüplerin ekonomik sorunlarından ötürü çoğu transfer paralarını aylarca, hatta yıllarca alamıyor, çaresizleri oynuyorlar" saptaması da ligler arasındaki adeletsizliği vurgulamaktadır.

Sporcuların karşılaştıkları diğer sorunlar ise sosyal sorunlardır. Selamoğlu (2003), ortak değerlerin ve amaçların tanımlanması, işgücünün, sosyal risklerinin kontrol altına alınması, sosyal risklerin olası sonuçlarının yönetilmesi ve sosyal dışlanma ve sosyal fonksiyonlarla ilgili engellerin, futbol kulüplerinin kurumsal yönetim becerisi, kulüp kültürü, örgüt bağlılığı ve iş doyumu ile ilgili olduğunu belirtmiştir. Cengiz (2008)'e göre sosyal sorunlar; sosyal çevreden izole etme, çirkin bir lakap takarak seslenme, toplum önünde küçük düşürme, uzun süreli her tür kötü muamele, suçlama, ima, kinaye, dedikodu, tehdit ve aşağılama gibi tekrarlanan olumsuz davranışlar olarak ortaya çımaktadır. Katılımcılardan sendikasız GK8 (Süper Lig) "Her yerde kıskançlık ve dedikodu var", sendikasız GK11 (1. Lig) "Her yer aynı, dedikodu yapılıyor", sendikasız GK25 (2. Lig) "Kıskançlık, insanın doğasında var, onun yerinde olmak istiyorsun", sendikasız GK34 (3. Lig) "Bu kadar kamp ortamı var, insanlar ne konuşacak. İster istemez bir mevzu açılıyor, dedikodu yapıyoruz", sendikasız GK21 (2. Lig) "Sadece keyfi olarak kadroya alınmama, 
yedek bekletilme, ödemeleri geciktirme, sakatlı süresince sahip çımama gibi bazı engelleme ve baskı altına almalar var, bunun dışında kıskançlık ve dedikodu edenleri saymıyorum. Bunlar zaten her yerde var" ifadeleriyle futbolcuların sosyal sorunlarla ilgili düşüncelerini genel olarak bizlere aktarmaktadır. Karşılaştırmaların kimi zaman her yerin aynı olduğu yargısıyla ve kişilerin durumu normalleştirebildikleri bir sosyal psikolojik süreçle sonuçlandığı düşünülmektedir. Araştırmamızda yer alan futbolcuların bir kısmı "her takım aynı" söylemini ortaya koymuşken ve bunu normalleștirme, durumu kabullenme, bireysel veya kolektif bir karşı çıkış sergilememe gibi durumlar ile birlikte anlatmışken, üç katılımcı "istisna" söylemine başvurmuștur.

Futbolcuların karşılaştıkları sorunlara yönelik olarak ortalama, on yıl altı farklı kulüpte futbol oynayan katılımcımız sendikalı GK4 (Süper Lig), "Dedikodu futbolda normaldir, futbol göreceli bir oyundur ve herkes herşeyi konuşur" șeklindeki ifadesiyle dedikodunun futbolun doğasında olduğunu belirtmiştir. Katılımcının "Şampiyonluk amaçlarıyla, kurulan pek çok takım var. Lig uzun bir maraton; sakatlık, ceza veya formunda olmama durumları olabiliyor. Bazen takımda rekabet yaratmak için transfer yapılıyor. Bu nedenle kadro geniş tutuluyor. Doğal olarak herkes oynamak, para kazanmak istiyor. Bu ortamda gruplaşmalar, kıskançlıklar veya dedikodu edenler oluyor" şeklindeki söyleminde ortaya koyduğu "Așırı rekabet var. Herkes oynamak, para kazanmak istiyor" söylemine göre dedikodu ve kıskançlığın varlığının kabul edildiği düşünülmektedir. Katılımcının sendikal mücadelenin zaten bir şeyi değiștirmeyeceği, kişinin yalnızca kendi vaktinin harcanması ve futbol camiasında kulüp yönetimleri tarafından mimlenmekle kalınacağının kabul edilmiş olduğu düşüncesinin oldukça önemli olduğu düşünülmektedir. Süper ig takım yöneticisi CÇ' nin istifa demecinde "Görev aldığım şehrin içindeki dedikoduların dışında, genel itibariyle Türk futboluna hizmet etmeye çalışan insanlara karşı bir karalama kampanyası yapıllyor" (Hürriyet, 2018) sözleri görüşmeci futbolcuları destekler niteliktedir.

Kulüp ortamında yaşanan sorunlardan bir başka unsur da olumsuz çalışma şartlarının varlığı olduğu düşünülmektedir. Profesyonel sporcuların çalışma koşullarının zor olması, üstünde durulması gereken bir sorun olarak görünmekte, bu durumun, kulüp ile futbolcu arasındaki örgütsel bağı, futbolcular arasındaki kaynaşmayı, grup bütünlüğünü ifade ettiği gibi gruplaşma, dedikodu, kıskançlık gibi olumsuzluklara da davetiye çıkarma riski taşıdığı söylenebilir. Dünya Kupası için stadyumlar inşa edilirken, Brezilya'daki profesyonel oyuncuların hâlâ idealden uzak şartlara katlanmak durumunda olduğunu söyleyen, Brezilya milli takımı oyuncularından Gilberto Silva "Kötü sahalar, pespaye soyunma odaları ve son zamanlarda gördüğümüz gibi güvenlik meseleleri. Avrupa ülkeleriyle Brezilya arasındaki altyapı ve mali durum farklarını biliyoruz. Ama bu, çözülebilir sorunları görmezden gelmemiz için bir sebep olmamalı" demeci bu sorunun futbolun genel bir sorunu olduğunu göstermesi açısından anlamlıdır (Diken, 2014).

Balcı (2017)'ya göre sporcuların antrenman veya müsabakalarda sakatlanması ve iş kaybına uğraması durumunun kulüp tarafindan bir dereceye kadar karşılanması, futbolcuları tedirgin eden davranışların varlığına işaret etmektedir. $\mathrm{Bu}$ durum futbolcuların çoğunun sakatlanmalardan kaynaklanan bir kriz yaşamasına, sakatlık nedeni 
ile sahalardan uzak kalma ve gelecek korkusunu aşamamasına, Türkiye'de profesyonel ligdeki sağllk denetimlerinin düşünüldüğü kadar iyi olmamasına yorumlanabilir. Günümüzde profesyonel futbolcu sözleşmelerindeki kulübe yüklenen yükümlülüklerde "Hastalık ve sakatlığa dair maddelerdeki esaslar dahilinde futbolcunun sağlığı ile ilgilenmek, müsabaka, antrenman, kamp ve seyahatlerde gerekli tedbirleri almak" gibi bir madde yer aldığı görülmektedir (TFF). Ancak bunun süresi ve çeşidinin belirtilmediği görülmekte; bu eksikliğin özel hükümlerle sağlanabileceği düşünülmektedir. Ayrıca sendikal haklar ve sözleşme hükümlerinin görüldüğü alanlar genellikle profesyonel futbolcu sözleşmelerinde tanımlanmış olmasına rağmen yaygınlaştırılmış uygulamaların sorgulanmasının gerekli olduğu düşünülmektedir.

Profesyonel futbolcuların sözleşme yapmadan önce doktor muayenesinden geçmeleri ile sakatlanmaları karşıllğında kulübün ya da sakatlayan tarafin nasıl bir tazmine gideceğine yönelik (sözleşmelerde kısmen yükümlülük yer alsa da) bugün açılığa kavuşmuş çalışma haklarının olmadığı görülmektedir (Petek, 2002).

Araştırmanın bir başka değişkeni olan özlük haklarının korunması konusunda futbolcular arasında ciddi anlamda bir belirsizliğin olduğu görülmektedir. Sendikasız GK39 (3. Lig) transfer ve prim ödemesi için federasyona şikayetini iletmiş, ancak bunun arkasından "kadro dışı bırakılma, şehir merkezine $40 \mathrm{~km}$ uzaklıkta ilçe sahasında alt yapı antrenörü eşliğinde antrenman yapmak gibi" yönetimin daha da ağır koşullar dayatarak kendilerini "cezalandırdığını" anlatmıştır. Bunun üzerine diğer arkadaşları "Sana bir şey değişmez demedik mi? Bu adamlar güçlü, niye şikayet ediyorsun? Sorun olmayan kulüp mü var? Bizimde paramız içerde, şikayet ediyor muyuz?" diyerek kendisini eleştirmiştir. Bu deneyimin kendisini "yıprattı̆̆ını" anlatan sendikasız GK39, "Genel olarak yanlızlık, insanı dirençsiz bırakan bir şey, bu psikolojiden kurtulmak kolay değil" demiştir. Bu durum bütün lig kategorilerinde yaşanmakla birlikte, alt liglere gidildikçe bu etkinin arttı̆̆ düşünülmektedir.

Sendikalı katılımcllardan GK5 (Süper Lig) "Federasyona şikayet etmeye, kaygılı yaklaşıyorum. Acaba bu benim futbol ve sonrası antrenörlük hayatımda önüme çıkar mı korkusu var", sendikalı katılımcılardan GK 7 (1. Lig) ise, "Bu sezon transferim var, transfer yapmak kolay değil, o yüzden kulüpleri şikayet etmeye çok olumlu bakamıyorum" görüşlerini belirtirken, sendikasız GK 19 (2. Lig) "Sorunlu bir futbolcu olarak görülmek istemiyorum." görüşünü belirtmiştir. Bu noktada katılımcılardan sendikalı GK5 ve GK7 ile sendikasız GK19'un ifadelerinin benzer olması dikkat çekerken, ayrıca futbolcuların neleri göze alamayacağını ortaya koyan bu sözler, kolektif bir mücadeleye girmektense bireysel seçeneklere yönelmeyi tercih ettiğini de ortaya koymaktadır. Bu duruma yönelik görüşmecilerin de belirttiği gibi "Bu şartlarda çalışan, ekonomik özgürlüğü ve çalışma güvencesi olmayan futbolcuların herhangi bir kulüp ve federasyon yönetimine karşı gelmesi son derece zor" olacağı söylenebilir. Futbolcuların, şikayet etmemenin daha doğru olacağı düşüncesinin, öğrenilmiş çaresizlik gibi işlev gördüğü de söylenebilir. Bu güçsüzlük hissinin doğurabileceği bir özsaygı yitiminden kaçınmak için de haksızlıklara itiraz edilmediği görülmektedir. Ayrıca olaya herhangi bir tesiri olamayacağından emin olan 
görüşmeci, itiraz ederse futboldan uzaklaştırılabileceği olasılığından hareket ederek, kendini güvenceye alabileceğini düşünmektedir.

Alacakları yüzünden TFF'ye şikayette bulunan katılımcı futbolcunun;, kulüp başkanı ve yakınındaki kişilerce darp edilmesi, bir başka futbolcunun kadro dışı bırakılması, bireysel antrenör tarafından başka tesislerde antrenman yapmaya mecbur bırakma, medya yolu ile taraftar gruplara hedef gösterilmesi veya keyfi cezalar verilmesi gibi etik dışı davranışlara maruz kaldığı saptanmıştır (Birgün, 2017). Spor medyasında, alacakları yüzünden TFF'ye şikayette bulunan bir futbolcu için de "Ceza gelebilir" manşeti bu gibi durumlarda beklenen yönetici tutumun göstermesi açısından da anlamlıdır.

Kısa bir çalışma hayatının olması ve faal spor hayatı sona eren sporcuların yaşamlarını güvence altına alabilmeleri için sendika kavramının önemli bir kavram haline gelmesi gerektiği düşünülmektedir. Sendikalaşma, sporcuların ve spor işyerlerinin sağlık şartları ve dopingle mücadele konusundaki uygulamalarla sporculara önemli yararlar sağlamaktadır (Üçışık, 2011). Buna karşın futbol sektöründe sendikalaşmaya olumsuz etkide bulunan faktörlerden bir tanesi aktif futbol yaşamının bitirilmesi korkusudur. Sendikalı GK6 ile sendikasız GK9, GK24 ve GK31'in "kulüpler transfer zamanı birbirlerini arayıp soruyor, futbol hayatım biter" ifadeleri de bu saptamayı destekler niteliktedir. Ayrıca Brezilyalı milli futbolcu Silva'nın, futbol sendikasını kastederek, bu sağduyu hareketine katılmasının ardından Atlético Mineiro kulübünün sözleşmesini yenilemediği ve hiçbir kulüpte forma bulamadığını belirtmesinin, çalışma bulgularını destekler nitelikte olduğu düşünülmektedir (Diken, 2014).

Katılımcı futbolcuların örgütlenme yaklaşımlarının, olumlu ve olumsuz olmak üzere iki tema altında toplandığı sonucuna ulaşılmıştır. Mevcut tablonun genel hatlarına bakıldığında; spor çalışanları arasında sendikal örgütlenmenin çok düşük oranda olduğu, var olan örgütlenmenin ise çalışanlar lehine olumlu sonuçlar sağlayabilecek yeterli güce sahip olmadığı anlaşılmaktadır. Sendikalı katılımcılardan GK3’e göre “özellikle süper lig'deki futbolcular örgütlenemez! Neden mi? Çünkü herkes kendinin lideri, futbolu çok iyi biliyor, çok yetenekli, yaratıcı, yönetici ve egosu kabarık. Bu nedenle, sendikanın bir hak arama örgütü olduğunun farkında değiller. Özellikle genç futbolcular sendikayı ve sendikanın yararlarını bilmiyor" ifadesi alanyazında Yıldız (2015) tarafından kaleme alınan "Türk futbolunda sendika olur mu?" başlıklı köşe yazısında; dönemin Bursaspor Teknik Direktörü Şenol Güneş'in, bir televizyon kanalında Türk futbolunun sorunlarını sıralarken bir futbol sendikasının olmamasından yakınmasına dair araştırma bulgusuyla tutarlılık göstermektedir. Bununla birlikte sendikasız katılımcıların görüşlerini ele aldığımızda ise GK18 "Hakkımı federasyon yoluyla arayabiliyorsam, neden sendikaya ihtiyaç duyayım?", GK12 "İyi bir futbolcunun sendika üyesi olmanın getireceği güvenceye zaten ihtiyacı yoktur. Ben de üst düzey bir futbolcuyum, sendikaya üye olmaya niye ihtiyacım olsun ki?", GK9 “Bir araya gelinebilir, ama sonuç odaklı bir değișim yaratılabileceğini düşünmüyorum. Bir de tabii karşınıza aldığınız sistemler düşünüldüğ̈nde, çok da gerçekçi gelmiyor açıkçası maalesef. Üst liglerde kimse umursamıyor, alt ligler de oynayanlar başka havalarda, düşünmek isteyenlerde güçsüz. Başkan ne derse, o oluyor, ne değişecek ki” şeklindeki futbolcuların neleri göze alamayacağını ve sendikalaşmanın anlamsız olduğunu ortaya 
koyan bu sözler, futbolcuların kolektif bir mücadeleye girmektense bireysel seçeneklere yönelmeyi tercih ettiğini de ortaya koymaktadır. Futbolcuların, örgütlenmeyi (çok isteseler de) mümkün görmediklerini kınayıcı bir tarzda ifade ederken, çoğunun hiçbir örgütlenme çabası içine girmeden var olan dayanışma ağından habersiz olduğu bulgularının, oldukça dikkat çekici olduğu düşünülmektedir.

Bunun yanı sıra, futbol insanlarının örgütlenmeye şüphe ve umutsuzlukla yaklaşmasının temelinde, Türkiye koşullarına duyulan güvensizliğin, kulüpten kovulma veya transfer yapılamaması korkusu ve Türkiye'deki örgütlü mücadele geçmişinin zayıflığından kaynaklanan inançsızlığın da olduğu söylenebilir. Örneğin sendikalı GK3; "Futbolcu odaklı bir değișim yaratılabileceğine inanmıyorum" derken, sendikalı GK2, GK7 ve sendikasız GK11 ise; "Daha önce futbolcu sendikası kurma deneyimlerinin kulüpten kovulmalarla sonuçlanmış olmasından da hareketle, Türkiye'de profesyonel futbol adamları için sendika kurmanın zor olduğu sonucuna varmaktadır.” Görüşlerini ileri sürmektedirler. Buna ilaveten sendikalı GK4 ile sendikasız GK8 ve GK12 ise özellikle aktif futbolcuların bir araya gelerek koleftif çözüm aramalarının pek mümkün görmediğini belirtmşlerdir. Elde edilen bu bulgu, futbolcular ve sendikalar arasındaki birlik ve dayanışma duygusunun zayıf ve yeterli bilincin oluşmadığını gösterirken, aynı zamanda futbolcuların sendikal örgütlemeye yönelik bir yabancılaşma yaşadıklarına işaret etmektedir (Yıldız, 2015). Bu bulgu ıșığında sendikalı ve sendikasız futbolcuların ortak bir kaygı sahibi olduğu da ortaya koyulmaktadır. Konuyla ilgili futbol piyasasının özellikleri, ekonomik kaygilar, futbolcuların hissettikleri kadro dışı bırakılma ve kulüpten uzaklaştırılma gibi sosyal dışlanma korkusuna ek olaraksendikaların güvenilirlikleri sendikal örgütlenme imkanlarını etkileyen faktörler arasındadır. Bunun ötesinde, ülkemiz futbol yönetimi hususunda yapılan değerlendirmelerde, futbolcularında söz hakkına sahip olabilmesi kısa vadede önemli bir gelişme olarak değerlendirilmemektedir. Futbolcuların bir başa çıkma mekanizması olarak içine girdikleri umursamazlığın, mesleki dayanışmayı yıpratan bir iklimin oluşmasına neden olduğu düşünülmektedir.

Futbol sektöründe sendikaların düşük örgütlenme düzeyinde olmasının bir başka sebebinin de genel olarak sendikalara yönelik algı ve değerlendirmelerin negatif yönde olmasından kaynaklandığı düşünülmektedir. Sendikasız GK15 "Nedense güvenmiyorum." söylemiyle, sendikalara olan güvenin düşük olması ve sendikaların, futbolcuların haklarını yeterince savunmasına olan inancın yetersizliği, futbol sektöründeki sendikalara olan ilginin olumsuz etkilendiğini düşündürmektedir. Zelyurt ve Şaşmaz Ataçocuğu'nun(2014) sendikaya üye olmayan futbolcuların anket ve görüşme sonuçlarında ön plana çıkan "güvensizlik" oranının \%79 olması da araştırma bulgularını destekler niteliktedir. Öztuna (2016)'ya göre spor alanında sendikaların düşük örgütlenme düzeyinde olmasının sebeplerinden biri sendikalara yönelik düşüncenin olumsuz olmasıdır. Bununla birlikte, fazla gelir elde etmenin, futbolcuları sendikaya üye olma fikrinden uzaklaştırdığı, buna karşın fazla gelir elde edemeyen futbolcularında kulüplere karşı pazarlık güçlerinin az olmasının önemli etkenlerden olduğu söylenebilir. Futbolcuların, sendikaya güvenmesiyle ahlaki normlar arasında yakın bir ilişkinin bulunacağı varsayılırsa, bu sonucun sendikaya üye olmayan futbolcuların algısı açısından ahlaki standartlarda bir düşüşü işaret ettiği 
söylenebilir. Bu bağlamda sendika yöneticilerinin dürüst, adil ve ahlaklı davrancaklarına olan inançlarının olduğunu söylemek yanlış olmayacaktır. Ancak, sendikanın faaliyetleri hakkında güvensizlik yaratacak bir ipucu olmamasına rağmen bu algının "neden" ve "nasıl" oluştuğu başka bir araştırma konusudur. Güvensizlik yaratan faktörler iki önemli gösterge üzerinde yorumlanabilir. Birincisi sendika yönetiminin herhangi bir yolsuzluk ve rüşvet gibi yasa dışı işlere bulaşmıș olması olupikinci neden, sendika yöneticilerinin çalışkanlık, sorumluluk, sorun çözme gibi becerilerine olan güvensizlik olduğu söylenebilir. Bu soruya cevap veren sendika üyesi GK35 "bu tamamen bir önyargı, bizim hakkımızda herhangi bir yolsuzluk, şike, teşvik veya usulsüzlük gibi konularda açllan bir dava yok. Üstelik bu arkadaşlarımızla güvensizlik yaratacak bir iletişim ve etkileşimimiz olmamış, sendikamızın faaliyetlerine katılmamışlar, üye değiller... Nasıl bu kanıya vardılar, anlaşılır değil. Bu söylemlere göre, futbol çalışanları sendikasının olmasına rağmen futbolcuların, kulüplere karşı haklarını müdafaa etmesi anlamında bu tür girişimlerde bulundukları anlaşılmaktadır" şeklinde yorum bildirmiştir. Yukarıda sayılan birtakım engellerin dışında sendikal bilincin düşük olması da önemli bir sorundur. Çalışanların sendikaların fonksiyon ve faydalarına yönelik yetersiz veya yanlış bilgilendirilmiş olmaları sendikal bilincin oluşumu ve gelişimine ket vurmaktadır. Sendikalı GK7'nin ifade ettiği gibi futbol sektörünün (kamp, antrenman, seyahat vb.) sürekli yoğun yapısının, bu sektörde çalışanların, sendikal bilince sahip olsa bile sektörün sendikalaşmaya izin vermeyeceği düşünülmektedir. Özellikle Süper lig ve 1. lig futbolcularının sendikalar altında birleşme eğilimlerine pek sıcak bakmadıkları, sorunlarının çözümünde menajerleriyle ortak hareket ettikleri, sendikayı risk olarak algıladıkları söylenebilir.

$\mathrm{Bu}$ görüşlere karşıt olarak bazı katılımcılar; zamanında ödenmeyen ücretler, sporcuların lehine olmayan sözleşmeler, kötü çalışma koşulları gibi nedenlerden dolayı sporcuların haklarını koruyacak bir çatının olması gerektiğini ifade etmişlerdir. Örneğin, sendika üyesi olmayan katılımclardan GK9 (Süper Lig), "İyi olur, umutluyum", GK14 (1.Lig) "Olmaması büyük bir eksiklik”, GK16 (1.Lig) "Geç bile kalındı, örgütlenmek gerekir.” GK34 "Futbolun ıslahı için çok önemli bir yol olur.", GK40 "Sorunların çözümü için örgütlenmek şart”, sendika üyesi GK35 "Bu konuda da Avrupa'nın 100 yıl gerisindeyiz" demişlerdir. Spor Toto Süper Lig 4 büyüğünün kaptanlarının bir araya gelip sendikalaşma kararı almaları, kağıt üzerinde kalsa da olumlu bir gelişme olarak düşünülmektedir (Şaşmaz Ataçocuğu ve Zelyurt, 2016). Futbolcuların sendikalara yönelik algıları her nasıl olursa olsun, günümüz futbol kulüplerinde ekonomik vesosyal koşullar ile özlük hakları sorunları, sendikalara olan ihtiyacın devam ettiğini işaret etmektedir. Bu saptamada herhangi bir değer yargısı olmayıp gerçekleștirilen uygulamaların eskisinden daha iyi ya da daha kötü olup olmadığı düşünülmemektedir. Ancak yaşanılan ve tanık olunan birçok olayın, toplumsal bir sorunun yanında, yönetimsel bir sorunu da yansıtmasının, mümkün olmadığı düşünülmemektedir. Ancak sendikanın örgütsel ve kurumsal yapısının, toplumsal hayat etkinlikleri içinde nicel ve nitel olarak çok önemli bir yer tuttuğu, bu ilişkinin azımsanamayacak boyutlarda olduğunun da kabul edilmesi gerektiği düşünülmektedir. 
J. Maguire ve R. Pearton (2000), takım sporlarında oyunculara verilen hakların farklı kıtalarda oynanan sporlara göre değişiklik göstermekte olduğunu ifade etmektedirler. Onlar; Amerikan futbolu, buz hokeyi, basketbol ve beyzbol gibi spor dallarındaki Kuzey Amerikalı sporcuların sendikalașıp, kulüp sahipleri ile müzakereler yürütmelerine ve grev eylemlerine katılmalarına rağmen, daha fazla istihdam hakkı elde etmede yalnızca sınırlı derecede başarılı olduklarını belirtmektedirler (Beamish, 1988; Kidd, 1988; Maguire ve Pearton, 2000; Sage, 1990). Diğer yandan futbol özelinde yaptığımız araştırmanın sonucunda; profesyonel futbolcuların sendika konusunda olumlu bir algiya sahip olmadıkları, sendikaların üye bulmakta zorlandıkları, özellikle 2. ve 3. lig futbolcularının kulüpleriyle ihtilaflarının çözümü için ihtiyaç hissedilmesine karşın sınırlı rol oynadıkları saptanmıştır. Sendikal örgütlenmeyi düşünmeyen futbolcuların, sendikanın yararlarından haberdar olmamasına rağmen algısal olarak sendikaya gerek duymadıkları anlaşılmaktadır. Bir diğer tespit, bu algının dayanağı olarak sunulan ekonomik rahatlık, transfer görüşmeleri ve özlük hakları sorunlarında menejarlerin kullanılmasından dolayı gerek duyulmadığı ifadeleri olup bu futbolculardan daha iyi kariyer ve ekonomik özgürlüğe sahip dünya yıldızı futbolcuların sendikal faaliyetlerde aktif rol oynadıklarıdır. Örneğin Eric Cantona, "Sendikalara zaman zaman bizlerin tavsiyelerde bulunması gerekir (BBC, 2010)" derken, İngiliz Oyuncular Birliği adlı sendika ise Manchester United'ı David Beckham'ı "ikinci el bir araba gibi" satmaya çalışmakla suçlamıştı (NDTV Sports, 2007). Bununla birlikte aralarında dönemin Real Madrid kaptanı Iker Casillas ve dönemin Barcelona kaptanı Carles Puyol gibi İspanyol futbolunun önde gelen isimleri bulunan İspanyol Futbol Oyuncuları Sendikası, temeli "oyuncular ve kulüpler arasındaki ödemeler konusunda yaşanan uzlaşmazlığa" dayanan bir grev başlatmıștı. İlgili grevde; futbolcuların ödememelerin devam edebilmesi için güvence altın alınmış bir maaş fonu oluşturulmasını istedikleri ifade edilmektedir (BBC, 2011). Bu yanlış algının sözkonusu futbolcuların ekonomik özgürlügünden değil, entelektüel birikim eksikliğinden kaynaklandğını düşündürmektedir. Örneğin; İtalya Birinci Futbol Ligi (Serie A) takımlarında top koşturan futbolcular birliğinin (AIC), oluşturmak istediği yeni sözleşme şartlarını protesto amacıyla grev kararını basına açıklayan AC Milan'ın savunma oyuncusu Massimo Oddo; "beşinci hafta maçlarında forma giymeyeceklerini, yeni getirilen sözleşme şartlarıyla oyuncuların herhangi bir obje gibi alınıp satılabileceğini, bu durumun insan haklarına aykırı olduğunu" ifade etmiştir (Futbol Ekonomi, 2018). Oddo'nun "Yüksek maaş alıyor olmamız, haklarımızdan vazgeçtiğimiz anlamına gelmez" (Futbol Ekonomi, 2018) açılklaması, ekonomik özgürlügün sendikadan uzak durma gerekçesi olmadığını destekler niteliktedir.

Bunun yanı sıra birçok futbolcunun etiketlenme korkusu nedeniyle sendikalara üye olmadığı, sendika için çalışmaya isteksiz olduğu, sendikaların düzenlemiş olduğu etkinliklere katılımın çok düşük olduğu, futbolcuların kulüpleriyle ihtilaflarının çözümde sendikanın sınırlı rol oynadığı, hak arama noktasında menajerlerin daha fazla yol gösterici bir niteliğe sahip olduğu, sorunları sendikal mücadele yerine bireysel çabalarıyla aşmaya çalıştıkları, sendikaların diğer sendikalarla ortak hareket etme kabiliyeti gösterdiği tespit edilmiştir. 
Bu bağlamda, profesyonel futbolcuların sendikalaşmaya karşı olumsuz eğilimlerinde; futbolun maddi çıkarlar peşinde koşulan riskli bir alan olması, çalışma koşullarındaki belirsizliğin pratik kaygılara yol açması ve kulüp yöneticilerinin egemen olmasının belirleyici olduğu saptanmıştır.

Araştırma sonuçlarına dayalı olarak, sendikacılıkta sadece futbol çalışanlarını değil, diğer spor çalışanlarını da içine alacak şekilde ortak platformlar yaratılması önerilebilir. Ayrıca ileri araştırmalara yönelik, gelișen ve değișen şartlara göre sendika üyelerinin de görüşleri alınarak amaçların belirli aralıklarla yeniden gözden geçirilmesi önerilmektedir. Çalışanın özlük haklarının korunup geliștirilmesinde sendikal örgütlerin rolü küçümsenmemelidir. Ancak futbol sektöründe sendikalaşma oranının bu kadar düşük düzeyde kalmış olmasının şüphesiz birçok nedeni vardır. Bu nedenlerin daha net bir biçimde ortaya konulabilmesi için en azından sektör çalışanlarının ve sendika yöneticilerinin görüşlerine başvuran ampirik araştırmaların yapılması önerilmektedir.

Sonuç olarak sendikaların, kulüp futbolcu ilişkisinin geliştirilmesinde öncü rol oynaması istenmekte, sadece üyelerine değil tüm futbol çalışanlarına destek olması beklenmekte, kendileri hakkında tüm futbol çalışanlarını bilgilendirmesi gerektiği düşünülmektedir.

\section{Yazar notu:}

Bu çalışma 19-21 Ekim 2018 Gürcistan/Batum'da yapılan 2. International Academic Sport Research Congress'de sözel bildiri olarak sunulmuştur.

Yazışma Adresi (Corresponding Address):

Dr. Göksel YIKMIŞ

Bingöl Üniversitesi Fen Edebiyat Fakültesi, Felsefe Bölümü, BİNGÖL

ORCID: 0000-0003-2126-6003

E-posta: gokselyikmis@gmail.com 


\section{Kaynaklar}

1. Akcan, E., Polat, S. ve Ölçüm, D. (2017). Yönetici ve öğretmen görüşlerine göre sendikal faaliyetlerin okullara etkisi. Abant İzzet Baysal Üniversitesi Ĕ̆itim Fakültesi Dergisi, 17(3), 1101-1119.

2. Aksu, A. (1998). Öğretmenlerin sendikalaşma engelleri. Buca Eğitim Fakültesi Dergisi, 1(9), 24-30

3. Alay, S. (2007). Türkiye'de sporcu sendikalarinin hukuki olarak kurulabilirliği, sporcu sendikalaşmasinin sporcu ve sporda doğurabileceği sonuçlar. Gazi Üniversitesi Beden Eğitimi ve Spor Bilimleri Dergisi, 10(1), 49-58.

4. Atalay, A. (2012). Türk futbolunda sendikal süreç. Akademik Bakış Dergisi, 30, 1-16.

5. Aydın, U. (2009). Profesyonel spor sendikacılı̆̆ında İngiltere ve Türkiye'ye öneriler. Uluslararası Spor Araștırmaları Dergisi, 1(1), 4-18.

6. Aydın, U., Yüce, A., Yalız, D. ve Demirkaya, S. (2017). Türkiye'de profesyonel sporcuların çalışma koşulları ve örgütlenme eğilimleri. Çalışma ve Toplum Dergisi, 4(55), 1873-1912.

7. Balcı, V. (2013). Çalışan sporcular. T. Çağlar (Ed.), Ankara barosu spor hukuku kurulu Av. Ömer Remzi Arıkan armağanı içinde (s. 191-201). Ankara: Mattek Matbaaclık.

8. BBC (2010, Kasım). Cantona: Devrim banka boykotuyla başlar. Erişim Adresi: https://www.bbc.com/turkce/haberler/2010/11/101121_cantona.

9. BBC (2011, Ağustos). İspanyol futbolculardan grev kararı. Erişim Adresi: https://www.bbc.com/turkce/haberler/2011/08/110811_spanish_football_strike.

10. Beamish, R. (1988). The political economy of professional sport. J. Harvey ve H. Cantelon (Ed.), Not Just a Game: Essays in Canadian Sport Sociology içinde (s.141-158). Ottawa: University of Ottawa Press.

11. Birgün. (2017, Aralık). Şanlıurfaspor'da skandal: Kulüp başkanı futbolcuyu dövdü. Erişim Adresi: https://www.birgun.net/haber/sanliurfaspor-da-skandal-kulup-baskani-futbolcuyudovdu-194156.

12. Bostancı, Y. (2013). Futbol kulüplerinin iş sağliği ve güvenliğine ilişkin yükümlülüklerinin değerlendirilmesi, T. Çağlar (Ed.), Spor hukuku kurulu Av. İsmail İnan Armağanı içinde (s. 135156). Ankara: Ankara Barosu.

13. Cengiz, R. (2008). Profesyonel futbol kulübü yöneticilerinin dönüşümsel liderlik stilleri ile kulüplerinin örgüt sağliğı ve futbolcuların yıldırma (mobbing) yaşamaları arasındaki iliş̧i (Doktora Tezi). Gazi Üniversitesi Sağlık Bilimleri Enstitüsü, Ankara.

14. Creswell, J. W. (2005). Educational research: Planning, conducting, and evaluating quantitative and qualitative research. Upper Saddle River, NJ: Pearson.

15. Cumhuriyet. (2016, Temmuz). Şilili futbolcular grevde. Erişim Adresi: https://www.cumhuriyet.com.tr/haber/silili-futbolcular-grevde-570321.

16. Daud, Z. ve Tumin, S. (2013). The relationship between employees' need and the formation of trade union: The malaysian manufacturing company's experience. International Journal of Business and Social Science, 4(13), 124-134.

17. Diken. (2014, Şubat). Alex örgütledi, futbolcular greve gidiyor. Erişim Adresi: http://www.diken.com.tr/alex-orgutledi-futbolcular-greve-gidiyor/ adresinden erişildi.

18. Fanatik (2015, Nisan). Süper Lig kaptanlarının ortak kararı: Sendika. Erişim Adresi: https://www.fanatik.com.tr/super-lig-kaptanlarinin-ortak-karari-sendika-421860.

19. Furtun, B. (2013). Türk hukukunda sporcuların iş hukuku bakımından değerlendirilmesi. T. Çağlar (Ed.). Ankara barosu spor hukuku kurulu Av. Ömer Remzi Arıkan Armağanı içinde (s. 405-468.). Ankara: Mattek Matbaacılık. 
20. Futbol Ekonomi (2018, Eylül). Serie A'da futbolcular greve gidiyor. Erişim Adresi: http://www.futbolekonomi.com/index.php/futbol-ekonomi-yazarlari/716-strike-byplayers-to-halt-serie-a-in-italy-.html.

21. Gül, M. H. (2007). Eğitim çalışanlarının eğitim sendikalarına bakışı, beklentileri ve sendikaların eğitim çalışanlarına yönelik faaliyetleri ve beklentileri (Yüksek Lisans Tezi). Yeditepe Üniversitesi Sosyal Bilimler Enstitüsü, İstanbul.

22. Hak-İş (2013, Ocak). Futbol-Sen 1. olağan genel kurulu yapıldı. Erişim Adresi: https://www.hakis.org.tr/haberler.php?action=haber_detay\&id=475.

23. Hürriyet. (2018, 16 Mayıs). Konyaspor'da şok istifa. Erişim Adresi: https://www.hurriyet.com.tr/sporarena/konyasporda-sok-istifa-40838539

24. Irak, D. (2013). Hükmen yenik. İstanbul: Evrensel Basım Yayın.

25. Karaman, Ş. (2018, Kasım). Futbolda çılgın paralar ve sendikalaşmanın önemi. Erişim Adresi: http://www.viralspor.com/futbolda-cilgin-paralar-ve-sendikalasmanin-onemi-sukrukaraman.

26. Kayıkçı, K. (2013). Türkiye'de kamu ve eğitim alanında sendikalaşma ve öğretmen ile okul yöneticilerinin sendikalardan beklentileri. Amme İdaresi Dergisi, 46(1), 99-126.

27. Kidd, B. (1988). The elite athlete. J. Harvey ve H. Cantelon (Ed.), Not Just a Game: Essays in Canadian Sport Sociology içinde (s.141-158). Ottawa: University of Ottawa Press.

28. King, N. and Horrocks, C. (2010) Interviews in qualitative research. Sage, London.

29. Maguire, J. ve Pearton, R. (2000) The impact of elite labour migration on the identification, selection and development of European soccer players. Journal of Sports Sciences, 18(9), 759769.

30. Nasöz, P. ve Demirkol, Ş. (2014, Kasım). Türkiye'de turizm sendikalarının sorunlarının analizi. 15. Ulusal Turizm Kongresi, Gazi Üniversitesi Turizm Fakültesi, Ankara.

31. NDTVSports (2007, Şubat). Players' union slams United over Beckham. Erişim Adresi: https://sports.ndtv.com/football/players-union-slams-united-over-beckham-1617454.

32. Öztuna, B. (2016). Profesyonel Türk sporcularının sendikal hakları. International Journal of Science Culture and Sport. 4(2), 469-476.

33. Petek, H. (2002). Profesyonel futbolcu sözleşmesi. Ankara: Yetkin Yayınları.

34. Rummel, J. F. (1968), Eğitimde Araştırmaya Girişs (Çev: R. Taşçığlu). Ajans Türk Yayınları. Ankara.

35. Sage, G. (1990). Power and ideology in American sport. Champaign, IL: Human Kinetics.

36. Şaşmaz-Ataçocuğu, M. ve Zelyurt, M. K. (2016). Profesyonel futbolda emek-sermaye ilişkileri: alt liglerde ücret, sosyal güvence ve sendika olgusu üstüne nitel bir çalışma. Sportif Bakış: Spor ve Eğitim Bilimleri Dergisi. 3(2), 99-115.

37. Selamoğlu, A. (2003). İşçi Sendikacılığında Yeniden Yapılanma ve Örgütlenme Modeli. Kocaeli Üniversitesi Sosyal Bilimler Dergisi, (6), 63-98.

38. Şişman, Y. (2004). Uluslararası çalışma normları. Eskişehir: Anadolu Ünivesitesi AÖF Yayınları.

39. TDK Güncel Türkçe Sözlük. Erişim Adresi: https://sozluk.gov.tr/.

40. Tekeş, M. A. (2010). Öğretmenlerin sendikalardan beklentileri: İstanbul örneği (Yüksek Lisans Tezi). Beykent Üniversitesi Sosyal Bilimler Enstitüsü, İstanbul.

41. Sendikalar Kanunu. (1983, 7 Mayıs). Resmi Gazete (Sayı: 18040). Erişim Adresi: https://www.resmigazete.gov.tr/arsiv/18040.pdf.

42. TFF. Profesyonel Futbolcu Sözleșmesi. Erişim Adresi: https://www.tff.org/default.aspx?pageID=128.

43. Uluyol, O. (2014). Süper lig futbol kulüplerinin finansal performans analizi. Journal of Yasar University, 9(34), 5716-5731. 
44. Üçıșık, F. (2011). Spor hukuku. İstanbul: Ötüken Yayınları.

45. Yensi-Güven, S. (2013). Türk futbolunda sendika. T. Çağlar (Ed.). Ankara Barosu spor hukuku kurulu Av. Ömer Remzi Arıkan armağanı içinde (s. 829-842). Ankara: Mattek Matbaacılık.

46. Yıldırım, A. ve Şimşek, H. (2013). Nitel araştırma yöntemleri (9. Baskı). Ankara: Seçkin Yayıncilık.

47. Yıldız, İ. (2015, Ocak). Türk futbolunda sendika olur mu? Erişim Adresi: https://www.haberturk.com/yazarlar/ibrahim-yildiz/1035905-turk-futbolunda-sendikaolur-mu

48. Zelyurt, M. K. ve Şaşmaz Ataçocuğu, M. (2014). Victims of age restrictions in Turkish football: A study on the social consequences of the application. Turkish Journal of Sport and Exercise, 16(1), 8-17. 